\title{
The Watch Smasher Argument [A Better Explanation]
}

\author{
Mister SA* \\ Independent Researcher, Nigeria
}

\section{Opinion}

“Occam's Razor is a scientific and philosophical rule that entities should not be multiplied

ISSN: 2578-0379

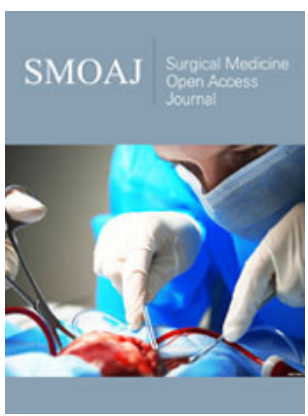

*Corresponding author: Mister $\mathrm{SA}$ Independent Researcher, Nigeria

Submission: 㭗 November 20, 2020

Published: 䟧December 04, 2020

Volume 4 - Issue 1

How to cite this article: Mister SA. The Watch Smasher Argument [A Better Explanation]. Surg Med Open Acc J. 4(1). SMOAJ.000577. 2020 DOI: 10.31031/SMOAJ.2020.04.000577

Copyright@ Mister SA, This article is distributed under the terms of the Creative Commons Attribution 4.0 International License, which permits unrestricted use and redistribution provided that the original author and source are credited. unnecessarily which is interpreted as requiring that the simplest of competing theories be preferred to the more complex or that explanations of unknown phenomena be sought first in terms of known quantity". [1] Merriam Webster Dictionary, in other words, Occam's razor says that, of two explanations that account for all the facts, the simpler one is more likely to be correct. "The greatest disorder of the intellect is to believe things because one wishes they were so" [2] Louis Pasteur, 1875. Supposing a man finds a watch. Deliberately or by accident the man smashes the watch to smithereens. The watch is reduced to particles. The man bashes the resultant particles with all his might, sets them on fire, drowns them in water, throws them to the wind, throws them into a volcano, launches them into a vacuum, exposes the particles to nuclear radiation and yet not only do these particles not get damaged or destroyed, but the particles come together and create another watch, identical to the destroyed watch! Is it not logical for the man to conclude that these particles made the watch? Now if this same man found a wheel, smashed it and found similar indestructible particles, though arranged in a different formation from the particles of the watch. Then the man found a shoe, pulverized it and reduced it to similar but yet differently arranged particles, only for the particles to recreate the wheel and shoe again. If this man stumbled upon a thousand other objects and experienced the same result it is logical for the man to conclude that these particles were the creators of those objects.

1. look around the universe and wonder how it came to be. Two scientific theories are laid before me. One says it all evolved. Another says it was all done by cellular dust.

\section{Why I Lean Towards the Cellular Dust Hypothesis/Microzymian Theory of Origin}

"In its simplest condition life, contrary to the idea of Aristotle, is independent of all special form; it resides in a substance defined by its composition and not by its shape [3-16]. It was then a legitimate conclusion that the microzymas of the calcareous rocks, of the clays, of the marls; in short of all the rocks which contain them, are the organized and LIVING remains of beings which had been living, of animals and plants of the geological epochs; that these beings were histologically constituted as are the beings of our epoch, that their microzymas, during their (the animals) destruction had become bacteria by evolution, and that the microzymas [cellular dust], geological ferments, of these rocks, are those of these bacteria destroyed in their turn and reduced to cellular dust. The microzyma is at the beginning and end of every living organization. It is the fundamental anatomical element whereby the cellules, the tissues, the organs, the whole, of an organism are constituted living. It is not surprising then that, having long pursued the anticipated consequences of the hypothesis now verified, I have demonstrated the presence of the microzymas in the earths of the garrigues of the departments of Herault and of Gard, in cultivated lands generally, in moor lands, in the alluvials, in the waters, in the dust of the streets, where they are to be found in crowds; often still in the condition of bacteria, proving that, like those of the calcareous rocks, they are energetic ferments. And already, prior to 1867, I had made known their role in the soil in agriculture.

These researches led to a result of very great importance; it was the demonstration that what was and still is called germs of the air are essentially nothing other than the 
microzymas of beings which have lived, but have disappeared or are being destroyed before our eyes. In fact, by precise experiments, I have proved that the microzymas of the air are ferments of the same order as those of the chalk, of the rocks, and of those of my experiments with artificial chalk; only, varying with the places, the circumambience and along with these microzymas, contain conides of lichens, spores of mushrooms, bacteria and everything that the wind can disperse in it. There is then no panspermy such as that which Charles Bonnet has invented, nor that which Spallanzani and Pasteur (after me) had admitted. In short. There are no pre-existing germs. At each period, as in our days, and in each place, there exist in the surrounding air only the microzymas of former beings which had disappeared and are disappearing with the things which the wind scatters in it.

But if we reflect that the species of microzymas are: first, as numerous as the species of eggs, of seeds, of spores of the various species of animals and plants; next, that there are in each animal and vegetable organism, already developed or in process of development, microzymas as specifically numerous as there are anatomical systems and organs, tissues and special cellules in these organisms, it is easy to conceive that the species of atmospheric microzymas are present in enormous numbers. One can also understand the very great number of changes which these microzymas may cause, when some one of these species fall into a fermentescible medium in which it can multiply, and either evolve in it, or build in it a cellule, or a mould. If then, as I have demonstrated experimentally, there are besides microzymas, and as well in animals as in plants, among the microorganisms of the circumbient air, spores, confides of fungi, of lichens, even actual cellules of ferments, it is easy to understand that if these microorganisms fall into fermentescible media they will develop in it, each according to its nature, and that various productions, moulds, diverse cellules, and at the same time vibrioniens, may appear in it. But in all the observations and in all the experiments relative to the spontaneous change of natural vegetable and animal matters, and in the fermentation of sugar or of feccula by aid of the tissues and humors of animals, when the influence of the micro-organisms of the air has been destroyed or suppressed, only microzymas and vibrioniens, and vibrios or bacteria, fruits of their evolution, are seen; this proves that the microzymas asre autonomous anatomical elements existing in it of themselves" [17].

\section{Why I have reservations about evolution}

In 1859 On the Origin of Species appeared. Ever since the theory of evolution has not been without its critics and scandals viz-

A. "Evolution is baseless and quite incredible" [18]

B. "Evolution, in very simple terms, means that life progressed from one-celled organisms to its highest state, the human being, by means of a series of biological changes taking place over millions of years" [19].

C. "When we descend to details, we can prove that no species has changed [we cannot prove that a single species has changed]; nor can we prove that the supposed changes are beneficial, which is the groundwork of the theory." Who am I to believe a theory whose proponent himself (Charles Darwin) does not fully believe? [20]

D. "To suppose that the eye with all its inimitable contrivances for adjusting the focus to different distances, for admitting different amounts of light, and for the correction of spherical and chromatic aberration, could have been formed by natural selection, seems, I freely confess, absurd in the highest degree" [21].

E. "The eye appears to have been designed; no designer of telescopes could have done better" [22].

F. Hoaxes Galore-In 1912, the evolutionist Charles Dawson created the infamous "missing link" Piltdown Man fraud. Why make fake a fossil and present it to the scientific community if there was a real one/if he really believed in evolution? In 1922 another hoax by evolutionists called Nebraska Man "Hesperopithecus haroldcookii" appeared.

G. "It is not the duty of science to defend the theory of evolution, and stick by it to the bitter end, no matter which illogical and unsupported conclusions it offers. On the contrary, it is expected that scientists recognize the patently obvious impossibility of Darwin's pronouncements and predictions. Let's cut the umbilical cord that tied us down to Darwin for such a long time. It is choking us and holding us back" [23].

H. 'Scientists who go about teaching that evolution is a fact of life are great con men, and the story they are telling may be the greatest hoax ever. In explaining evolution, we do not have one iota of fact' [24].

I. "The theory of evolution suffers from grave defects, which are more and more apparent as time advances. It can no longer square with practical scientific knowledge" [25].

J. "The theory of evolution is totally inadequate to explain the origin and manifestation of the inorganic world" [26].

K. "The theory of evolution is a scientific mistake" [27].

L. "Scientists have no proof that life was not the result of an act of creation" [28].

M. "It is unphilosophical to pretend that it (the world) might arise out of chaos" Sir Isaac Newton [29].

N. Evolutionists once emphatically stated that junk DNA was proof of evolution. We had inherited it from our ape-like ancestors. Later it was found out that "junk" DNA was performing some functions in the human body [30].

0. The evolutionist Ernst Haeckel forged drawings of human and animal embryos to prove the Ontogeny recapitulates phylogeny aspect of evolution. He was caught and the actual embryos of humans and other animals was found to be distinct. Other frauds perpetuated by evolutions include the hydracotherium to horse fraud and vestigial organs fraud. Many of those organs called "vestigial" have now been found to have functions. The theory of evolution is quackery. 
Two years ago, I proposed the cellular dust hypothesis of the origin of life and the universe. This remarkably simple theory states that the universe and all life therein arose and is sustained via activities/chemical reactions carried out by ubiquitous microscopic entities called microzymas/cellular dust. I hereby invite and challenge scientists from all over the world to assess, approve of, critique or refute the theory.

\section{References}

1. Seun A (2018) A new origin of life and the universe proposed microzymian. Peer Reviewed Journal of Forensic \& Genetic Sciences 1(5): 1-84.

2. Ayoade $S$ (2019) A new natural law proposed-S.A.L.L.T. Emerg Infect Dis Diag J, GRF Publishers, Australia.

3. Seun A (2018) Could microzymas be the elusive dark matter? Could microzymas be the force behind dark energy? Peer Reviewed Journal of Forensic \& Genetic Sciences 1(5): 87-88.

4. Seun A (2018) Re-examining time and time travel in the light of the microzymas. Peer Reviewed Journal of Forensic \& Genetic Sciences 2(4): 149-150.

5. Seun A (2019) The cellular dust hypothesis and the laws of thermodynamics. Global Journal of Anesthesia \& Pain Medicine 1(2): 45-46.

6. Seun A (2019) Another theory for phantom pain. Global Journal of Anesthesia \& Pain Medicine 1(5): 1-92.

7. Seun A (2018) Microzyman Theory of Origin (MTO)/ Cellular Dust Hypothesis $(\mathrm{CDH})$-matters arising. Peer Reviewed Journal of Forensic \& Genetic Sciences 2(4): 142-143.

8. Mister SA (2019) Please patiently pick per person-pedadogue, pretender, plagiartist, pilferer. Biomedical Journal of Scientific \& Technical Research 16(5): 12380-12382.

9. Ayoade S (2017) Koch's postulates and germ terrain dualism; cellular dust as yet another term for microzymas. J Mol Genet Med 11: 4.

10. Seun A (2019) Introducing SAMS. Journal of Endocrinology and Disorders 3(1):

11. Seun A (2019) Spontanous human combustion-are the microzymas the culprit? Res \& Rev Health Care Open Acc J 3(3).
12. Seun A (2020) Isaac newton's "Active principles, particles" and the cellular dust hypothesis; Rewriting cytology and histology in the light of S.A.M.S. Journal of Clinical Epidemiology and Toxicology 1(1): 1-2.

13. Seun A (2020) The cellular dust hypothesis and parapsychology; Open call for more kirlian experimentation. Journal of Physical Medicine Rehabilitation Studies \& Reports 2(3): 1-1.

14. Seun A (2020) Principles of citoportation. Biomed J Sci \& Tech Res 25(5).

15. Seun A (2020) A rational and scientific explanation for metempsychosis. Archives in Neurology \& Neuroscience 7(4): 1-2.

16. Bechamp A (1911) Blood and its third anatomical element. Kessinger Legacy Reprints, Montana, USA, 205(197-199): 136.

17. Ambrose F (1964) President, British Association for Advancement of Science, in The Unleashing of Evolutionary Thought. p. 6.

18. Charles Darwin (1887) The life and letters of Charles Darwin 2: 210.

19. Charles Darwin (1909) The Origin of Species (1909 Harvard Classics edition), p. 190

20. Robert Jastrow (1981) The enchanted loom: Mind in the Universe, p. 98.

21. Cohen LL (1985) Darwin was wrong: A study in probabilities.

22. Tahmisian TN Physiologist for the Atomic Energy Commission

23. Albert Fleishman, zoologist.

24. Sir Ambrose Fleming (2020) Discoverer of the thermionic valve.

25. Louis Agassiz (1986) quoted in H Epoch, Evolution or Creation, p. 139.

26. Robert J (1981) The enchanted loom: Mind in the Universe, p. 19.

27. (1704) Query of optics.

28. Michael LP (2017) At least 75 per cent of our DNA really is useless junk after all.

29. (2005) UCSD Study Shows 'Junk' DNA has evolutionary importance.

30. Stephen SH (2012) Hidden treasures in junk DNA what was once known as junk DNA turns out to hold hidden treasures, says computational biologist Ewan Birney.

For possible submissions Click below:

Submit Article 